\title{
State Autonomy in Shaping Tax Policies: Facts and Myths Based on the Situation in OECD Countries
}

\author{
Jacek Tomkiewicz ${ }^{1}$, Marta Postuła²
}

Submitted: 17.12.2019. Accepted: 25.05.2020

\section{Abstract}

Purpose: Capital flows, tax competition, multinational companies and tax havens weakens governments' ability to lead independent tax policy. This race to the bottom, especially in the case of CIT rate, seems to work. Aim of the text is to show that the governments are not as powerless as it is often claimed. Despite common opinion, nation-states retain a relatively significant autonomy in creating their own fiscal policies, including tax instruments. Size of funds kept in tax havens have not been growing for few years and international cooperation of tax authorities is more and more efficient in dealing with the tax fraud.

Methodology: The study uses desk research method for theoretical reasoning to verify the research hypothesis. Moreover, the study seeks answering if the application of EU tax policies determines national tax policy. To that end, the authors utilize time series and cause-effect analysis, as well as quantitative research for the systematization of statistical information and regression analysis for the examination of statistical dependencies. Tax competition or the functioning of tax havens naturally limits the realization of the fundamental functions of fiscal policies, although the taxation remains one of the most crucial instruments of macroeconomic and income policy of national authorities.

Findings: The most important data on public revenues structure in different OECD countries indicate that taxation remains one of the most crucial instruments of macroeconomic and income policy of national authorities. We also show that impact of FDI on hosting economy is not as positive as it is said to be. There is no relation between FDI and R\&D spending and level of wages in hosting country is even affected in the negative way by the FDI inflow. Irrespective of the regulatory details introduced at the EU level - the basic factor affecting jets coordination in the field of cooperation between tax services brings effects both in terms of the current collection of tax liabilities and the creation of regulations that hinder tax avoidance and under statement assessment.

Originality/value: The study focuses on an analysis of tax policy. The view that taxation of international corporations is fraught with difficulties finds support in the undeniable reality of tax competition. Moreover, a large and growing share of profits is transferred to low-tax places. The prospects for taxing international companies with positive rates seem unoptimistic. Therefore, it is essential to check how the national economy is affected by the FDI inflow in OECD countries.

Keywords: tax competition, tax autonomy of states, tax havens, tax policy

$$
\text { JEL: H10, H2O, K34, G31 }
$$

Kozminski University, 59 Jagiellonska St., 03-301 Warsaw, Poland; e-mail: tomkiewj@alk.edu.pl; https://orcid.org/0000-0003-3509-621X.

2 University of Warsaw, 1/3 Szturmowa St., 03-678 Warszawa, Poland; e-mail: mpostula@wz.uw.edu.pl; https://orcid.org/0000-00015502-9722. 


\section{Introduction}

Fiscal policies have always caused controversies, because it is difficult to find a more apparent example of state interference in the functioning of the market economy. When observing economic history, we clearly see that the role of taxes changed significantly. First, tax importance for the economy drastically increased: in the early twentieth century, taxes comprised less than ten percent of Gross Domestic Product in government revenue, whereas today, the mean value for the OECD countries equals 34.2 percent GDP. Second, while until the early twentieth century the role of taxes was confined to their fiscal function - fulfilling state demand for money - fiscal policies today serve as an attempt to achieve a vast array of socioeconomic and political goals, such as correcting market distribution of income, mitigating negative externalities, or creating impulses for the development of particular areas or segments of the economy. Simultaneously, one may notice that the advancement of globalization - particularly in the increase of capital movements - significantly limited the possibility of nation-states to conduct independent economic policy, especially fiscal policy (Andrews, 1994; Cheibub, 1998; Gilpin, 2000; Cerny, 1995). Already nearly twenty years ago, Tanzi (2000) coined the term "fiscal termites" to indicate that government revenue is slowly undermined by the following phenomena and mechanisms:

- the spread of e-commerce, which allows companies to omit national indirect taxes;

- the functioning of tax havens, which results in a decrease in revenue from income taxes (personal and corporate) and property taxes;

- the increase in the importance of international corporations, which have branches in various countries and can thus manipulate tax base in individual countries by means of transfer pricing;

- tax competition, that is the creation of incentives for locating capital in a particular country by lowering tax rates, mainly corporate income taxes;

- the growing scale of tourism and international business trips, which allows people to take advantage of differences in indirect tax rates of value-added tax and excise tax.

We commonly encounter claims that the "winners from globalization" - international companies, affluent households, highly qualified individuals - are difficult to contain in a tax system functioning in their place of origin (Zucman, 2014; Wright and Zucman, 2018; Torslov, Wier, and Zucman, 2018). Companies can relocate abroad or transfer profits to tax havens, while the rich can also relocate or hide their assets abroad. Does that mean state authorities become increasingly powerless and must admit that the efficacy 
of their instruments - taxation both in its fiscal function and in other policy goals - increasingly diminishes so that the public sector must seek different instruments or acknowledge its limited ability to influence the economy? To empirically verify the hypotheses that stem from the above research problems, we will employ a mixed methodology of qualitative and quantitative studies.

The purpose of the text is not a comprehensive quantitative analysis of tax policy and its determinants but instead a review of current research results in this area. Our conclusions are also based on a relatively simple quantitative study, whose purpose is to indicate the basic relationships between foreign investments and basic values that characterize given economies.

We based the qualitative study on descriptive analysis, and the quantitative study on the analysis of source statistical data and the methodology of statistical dependence so as to employ the method of statistical data systematization.

\section{The Increasingly Difficult Work of Tax Collectors}

Globalization is now a common phenomenon. In the European Union, the process of globalization commenced with single market solutions. The removal of barriers and harmonization of regulations exposed taxation differences and reinforced their effects (Garrett and Mitchell, 2001). Critical decisions of companies are increasingly tax-sensitive, including the localization of economic activity and taxable income. A product may be sold in country $\mathrm{X}$ after its creation in a value chain that can be distributed all over the world. The localization of particular steps of a value chain may be tax-sensitive. Currently, we observe a growth in the number of international transactions among entities with capital links (Bretschger and Hettich, 2002; Auerbach and Bradford, 2004). This concerns not only products but also indirect license fees, services, and interest on debt.

Tax havens are a relatively old phenomenon, even though their earlier existence answered the need to "hide" illegally earned wealth or protect oneself from political risks, not tax avoidance (Kudrle, 2008; Remeur, 2017; Oxfam, 2019). Along with the development of international banking, the popularization of the English language, electronic transactions, and most importantly, the release of international capital flows, tax havens have become the place of interest not only of criminal groups or fleeing dictators but also of powerful corporations and respected citizens from developed countries, who disagree with what they consider excessively high taxation. Noteworthy, the film image 
of a tax haven as a paradise island far in the ocean has little to do with reality: the majority of assets is hidden in Switzerland, some of the states in the USA, or on the British islands on the English Channel (Shaxson, 2016; Shaxson and Christensen, 2016; Sheppard, 2017). How large funds are located in tax havens and to what degree these assets are hidden from tax collectors is difficult to say because, after all, neither asset owners nor managers of offshore financial centers publish data on the size and structure of stored funds. Thus, scholars use indirect methods: utilize the research of anomalies in the balance of payments and follow the occasional "leaks" such as the Panama Papers. It is estimated that funds deposited in tax havens amount to as much as ten percent of the global GDP: today it means an enormous amount of eight trillion dollars (Johannesen and Zucman, 2017). The inclusion of funds gathered in tax havens into calculations significantly changes the distribution of wealth among particular countries. Mindful that the hidden assets predominantly belong to the richest, wealth inequalities suddenly appear even larger than these estimated on the basis of official data in particular countries. Thus, tax policies aimed at limiting income and wealth inequalities may not be very effective.

Bearing in mind that the structure of the majority of world economies changes in favor of the increasing consolidation of production - a group inclined to tax optimization - the rapid growth of the most profitable companies and subsequent waves of mergers and acquisitions have resulted in fewer but much more powerful corporations operating in the markets. The number of companies listed on the US Stock Exchange has been falling since 1997: the number today is lower than forty years ago (Kahle and Stulz, 2017). In 2015, there were as many as ten corporations among the 30 largest economic organizations in the world - with Walmart as the largest one positioned on the ninth position - while 69 among the 100 largest entities. Each of the ten biggest companies registers revenues higher than such significant national economies as Russia, Norway, or Switzerland (Zingales, 2017). Assuming a classic billing model, such a situation should be conducive to tax collection, because it should be easier to control a lesser number of entities. However, there simultaneously occur processes that do not facilitate the enforcement of corporate tax liabilities. First, companies internationalize, which allows them to use transfer pricing mechanisms to manipulate the tax base they demonstrate in individual countries. Second, the shareholding structure significantly changes in favor of the rapid growth of the importance of institutional investors (Beebeejaun, 2018). In the mid-twentieth century, only about $6 \%$ of the 1000 largest companies in the USA were owned by institutional investors; at the end of the first decade of the twenty-first century, this number grew to over seventy percent (Admati, 2017). Such a "dehumanization" of corporate ownership causes the lack of sentiment among shareholders, who would otherwise be reluctant to accept - on the moral and patriotic basis - that 
their own company is guilty of dishonest relationships with national tax authorities. Investment funds have no such dilemmas: there is no place for morality and national sentiments among them, because what only counts are their present financial results, which should naturally be taxed as low as possible.

The view that taxation of international corporations is fraught with difficulties finds support in the undeniable reality of tax competition. In 1985-2018, the average global statutory corporate tax rate decreased by more than half from $49 \%$ to $24 \%$. In 2018 , the USA spectacularly reduced its interest rate from $35 \%$ to $21 \%$. In a few years, this reduction may lead to an exacerbation of rivalry for the lowest corporate tax rate all over the world. In September 2016, Theresa May pledged to reduce the corporate tax rate in the United Kingdom after Brexit to the lowest rate among all the G20 countries. Many other countries announced their interest in further reductions in interest rates. For instance, France plans to lower this rate from the current 33\% to 25\% in 2022.

Moreover, a large and growing share of profits is transferred to low-tax places. The prospects for taxing international companies with positive rates seem unoptimistic. On a global scale, part of the decrease in corporate tax rates and loss of income due to shifting profits was compensated by broadening the base. However, in general, effective corporate tax rates significantly decreased, almost in line with the decrease of statutory tax rates (Zucman, 2014). Moreover, in the USA, the share of taxable corporate profits in the GDP decreased over time - due to the growth of non-corporate and tax-exempt sectors - which exacerbates the decline in the total number of corporate income tax revenues.

The scale of growth in international financial flows is best visible in the growing importance of international investments. In 1995, the stocks of foreign direct investments comprised $11.5 \%$ of the global GDP, whereas, in 2018, it amounted to as much as $38 \%$ (data in this paragraph is based on UNCTAD analysis: https:/unctadstat.unctad.org). Interestingly, capital does not flow from rich to poor countries, which should be supported by the rule of diminishing revenues, according to which marginal returns decrease along with the saturation of capital. Significantly more foreign capital is located in developed countries - $42 \%$ of GDP - than in developing countries where it amounts to $31.7 \%$ of GDP. The difference seems not high, but we should remember about the much higher level of income in rich countries, so the difference is huge in absolute numbers. We may suspect that the situation, in which capital flows to the rich countries, stems from tax policies pursued by the states that combine economic and political stability with low taxes or create a suitable environment for investing capital. 
Table 1. The taxation of business activity and foreign direct investment stocks in Ireland and Luxembourg

\begin{tabular}{|l|r|}
\hline \multicolumn{1}{|c|}{ Ireland } & $\mathbf{2 0 1 7}$ \\
\hline Effective CIT rate (\%) & 7.5 \\
\hline FDI stocks (\% GDP) & 297.8 \\
\hline \multicolumn{1}{|c|}{ Luxembourg } & 2017 \\
\hline Effective CIT rate & 6.8 \\
\hline FDI stocks (\% GDP) & 427.6 \\
\hline OECD - Average & \\
\hline Average effective CIT rate & 11.4 \\
\hline FDI stocks (\% GDP) & 50.1 \\
\hline
\end{tabular}

Source: own elaboration of OECD data.

The partial data in Table 1 shows that such "capital-friendly" places like Luxembourg or Ireland do attract investors. As a comparison, in Germany and France the level of FDI stock is just $29 \%$ and $23 \%$ of GDP. We used the data on foreign direct investments for analysis, not the one on short-term portfolio capital, so we may clearly see that tax competition indeed does occur: capital flows where it is taxed low so that the tax base decreases in its place of origin, which results in a decrease in inflows mainly due to corporate income tax.

\section{Tendencies in Tax Policies}

The above processes were reflected in the tax policies of OECD countries. Since the 1980s, it is apparent that governments react to the changing reality. Naturally, we may wonder to what extent do changes in taxes stem from discretionary decisions caused by the conservative revolution of the eighties, and to what extent are they adjustments to objective processes in economies? Nevertheless, it is a fact that:

- marginal rates fall (progression decreases) in personal income tax;

- increasingly more often the capital income of individuals is treated separately, not aggregated with income from work and subject to flat taxation;

- a growing share of corporate income tax receipts in public revenue is not visible despite substantial increases in the share of corporate profits in GDP; 
- we observe an intensification of tax competition, mainly in corporate income tax rates;

- the importance of indirect taxes in government revenue grows, particularly VAT;

- most OECD countries' budgets recorded permanent deficits until the outbreak of the 2008 crisis, despite a favorable economic situation understood as growing GDP combined with moderate inflation and unemployment.

Therefore, tax systems are decreasingly capable of fulfilling their role. Above all, public revenues "lag behind" growing public expenditures, which increases due to demographical and technological changes. This situation caused that - at the moment of financial crisis' outburst - room for implementing expansive fiscal policies was very limited. This crisis contributed to a livelier discussion about the current state of economics as a science and its actual role in decision-making and creating economic processes. The scholars and practitioners of this discipline try to define the causes of this situation (King, 2010; Legrain, 2010; Rajan, 2010; Massey and Thaler, 2012; Kołodko, 2016; Stiglitz, 2018). The economists attempt to find an answer to whether the crisis we recently encountered is only a symptom of the dysfunctionality of the economy or also of the applied fiscal policies? Some of the scholars presented quite a bold thesis that the modern economics failed because, on the one hand, it did not take advantage of dependencies - which would allow one to foresee the crisis - and, on the other hand, it was unable to offer effective remedies to prevent such phenomena in the future (Lin, 2012). The difference of opinions apparent among economists after the crisis is presented briefly and exhaustively by 2008 Nobel laureate Paul Krugman (2009), who writes:

Can anyone seriously claim that we've lost 6.7 million jobs because fewer Americans want to work? But it was inevitable that freshwater economists would find themselves trapped in this cul-de-sac: if you start from the assumption that people are perfectly rational and markets are perfectly efficient, you have to conclude that unemployment is voluntary and recessions are desirable.

Considering such a broad discussion conducted in a larger context, it is worth considering what shape the tax system should assume to keep pace with the changing reality. We now see that the redistributive role of taxes weakens, which may have previously seemed like a natural remedy for the deepening of income inequalities. However, tax policy aims exactly in the opposite direction: income tax progression decreases and a flat tax on income from capital becomes the standard, tax burden on inheritances and donations is reduced, while there grows the role of indirect taxes - which are degressive - thus, in sum, the public finance system increasingly flattens the market distribution in total income in the economy. 


\section{Are States Truly Powerless Against World Economy Trends?}

Earlier, we indicated a series of mechanisms and processes that significantly weaken the efficacy of fiscal policy in reaching the entire array of its goals. Should countries really "surrender?". This would mean a withdrawal from income taxes and an increase in the role of consumption taxes, which are harder to avoid, since consumption is much less geographically mobile and provides fewer opportunities for manipulating the tax base than in the case of income.

It is difficult to debate the above facts, but we should also recognize that the position of the nation-state as the subject that implements tax policy is not so weak as it is often depicted.

First, the role of tax havens in the modern economy is indeed significant, which undoubtedly hinders tax collection, but for at least a dozen or so years, the size of assets located in offshore financial centers counted as a percentage of the global GDP has not increased. The pressure of the public opinion, the inquisitiveness of investigative journalists, and primarily, the growing effectiveness of tax services of individual countries make hiding income and assets from taxation increasingly difficult, expensive, and risky. For instance, we should remember the Foreign Account Tax Compliance Act (FATCA) implemented in the USA in 2010, which orders foreign financial institutions to inform the USA about the financial assets of American citizens. The other important change is the decision of the UK, which requires shell companies registered on dependent territories like Gibraltar or the English Channel Islands to reveal their detailed ownership structure until 2020.

Second, the national structure of assets hidden in tax havens is surprising. The weight of the tax burden is not decisive, just the opposite. It is estimated that citizens of Scandinavian countries - with very high taxation - hide only a few percent of their assets, in continental Europe it amounts to about 15\%, while the biggest share of assets, as much as $60 \%$, is located in tax havens by entities from relatively low taxed places like Russia, Latin America, and primarily the countries of the Persian Gulf (Alstadsæter et al., 2017). Clearly, it is not the height of taxes that is the critical factor determining tax avoidance but rather economic-political instability and corruption, which fundamentally decreases the effectiveness of tax services.

As a side note, the example of Scandinavian countries is thought-provoking, because it shows that one can combine relatively high taxation with a highly effective economy. Sweden and Denmark lead not only in the quality of life indicators but also in such 
areas as employment level, international competitiveness, or engagement in research and development. High taxes are accepted if they come along with a high quality of public goods, a culture of respect for the public sector (with the stigmatization of tax avoidance cases), and high effectiveness of tax services, which have a large amount of data on taxpayers and possibilities of its analysis (Kleven, 2014).

Third, a closer look at the impact of FDI on the domestic economy presents a picture far from clear. Simple correlation between effective CIT rate and revenues from corporate taxation is very weak: positive with the result just at the level of 0.1 (correlation for OECD countries in 2017). It means that capital inflow brought by low taxation does not pay off in budget revenues. Data from Table 1 about the volume of obtained FDI does not clearly show that foreign investors locate their production and create jobs in economies such as Ireland, which applies low taxation primarily in corporate tax. We should also remember that the majority (about 60\%) of capital flows classified as FDI are not actual involvement in production processes but mergers and takeovers; that is, financial operations. So indeed, capital often flows, for example, to Ireland. However, it does so but not to create jobs and conduct research and development but to declare profits that are competitively low taxed. Noteworthy, the share of wages in the Irish GDP in 2017 is at a record low of $36.6 \%$ of GDP, in Luxembourg it is $56.2 \%$ of GDP, while in France and Germany it is $60.3 \%$ and $61 \%$ of GDP, respectively (ILO data). Therefore, one should not engage in a senseless tax competition that is supposed to attract investors, since not every foreign direct investment has a clearly positive impact on the real economy, understood as creating good quality jobs and technology transfers.

Simple quantitative model on OECD, ILO, and UNCTAD data (we present detailed results of the model in the next part of the paper) gives mixed results:

- there is a positive correlation between FDI inflow and GDP growth, which should be no surprise, because the inflow of production capital directly raises GDP,

- there is no statistically significant relation between FDI inflow and R\&D expenditures in the national economy, so there is no quantitative evidence that FDI inflow accompanies the high-tech activity of foreign and domestic businesses,

- there is a strong negative relation between FDI inflow and the share of wages in the GDP, so very often FDI is just a financial transaction made to change the national structure of a capital group, and the impact of capital inflow on the real economy of the host country is limited.

Fourth, indeed, the economic power of international corporations has never been as large as it is now, but the existence of such large entities provides the public sector with 
certain advantages. Functioning under well-recognized brands means the economic situation of a corporation can significantly worsen due to the boycott of consumers, who are also taxpayers. The British branch of Starbucks suffered from such a boycott in 2012, when it was revealed that during several previous years they "aggressively" lowered their tax base declared in the UK.

Large companies are so strongly engaged in individual markets that a loss of even one due to a hypothetical conflict with tax administration would be much more severe than paying taxes that the corporations prefer to deem undue. We may recall the example of Apple, which on the basis of the European Commission's decision in 2016 had to pay overdue taxes in Ireland, even when the Irish government directly announced that it sees no such necessity. Clearly, the threat of sanctions from the EU institution succeeded, as it would cause Apple difficulties in reaching European consumers with their products. Thus, if we hear that the EU works on a digital tax, it does not need to mean that the public sector is doomed to failure in the case of conflict with such giants as Google, Facebook, or Amazon.

Significant progress is visible also in terms of working on a concept of taxing international corporations. Work is underway in the OECD and the IMF (2019) to develop rules for paying taxes by entities that operate in different countries. The tax base will be divided according to the actual economic engagement in particular countries, and not according to declared revenues, which can be relatively easily manipulated. Another interesting approach is to establish financial results at the level of the entire company, so the application of transfer prices between branches in different countries would lose its rationale. The profit calculated in this way creates the tax base to which each country applies its own tax rate.

The above data clearly shows that even among countries at a similar development level, such as the economies of OECD members, the differences in the shape of tax policy are significant. After all, this relates to economies that implement practically no trade barriers and controls of capital flows in mutual contacts, so differences in the scale of implementing different kinds of taxes are clearly very high (see Table 2).

Therefore, it is not true that national governments are powerless and should withdraw from tax revenue in the face of free movement of commodities and capital, because somewhere in the world the rates of corporate tax and VAT are lower, so capital and consumption would transfer there. 
Table 2. Selected data on the tax policy of OECD countries. Tax revenue in $\%$ of GDP

\begin{tabular}{|l|c|}
\hline \multicolumn{1}{|c|}{ Total public revenues } & \% GDP \\
\hline Average & 34.2 \\
\hline Min & 16.2 \\
\hline Max & 46.2 \\
\hline & Corporate income tax \\
\hline Average & \\
\hline Min & 2.9 \\
\hline Max & 1.5 \\
\hline & 4.7 \\
\hline Average & \\
\hline Min & 11 \\
\hline Max & 4.3 \\
\hline
\end{tabular}

Source: own elaboration based on the OECD database.

\section{The Model: FDI Inflow and Its Impact on Host Economies}

The goal of the quantitative exercise is to check how national economies are affected by the FDI inflow. As a sample, we have chosen OECD countries. We measure FDI by its stock against GDP, and we take data from the UNCTAD database. We sought correlations between FDI inflow and variables like GDP growth, R\&D spending in millions of USD (data from the OECD), and the share of wages in GDP (data from the ILO database).

Table 3. Data used in the model

\begin{tabular}{|l|c|c|c|c|c|}
\hline \multicolumn{1}{|c|}{ Variable } & $\begin{array}{c}\text { Number } \\
\text { of observations }\end{array}$ & Mean & Std. Dev. & Min & Max \\
\hline FDI inflow & 448 & 43.68527 & 58.6999 & .6 & 427.6 \\
\hline GDP growth & 503 & 4.630616 & 5.16657 & -22.7 & 34.4 \\
\hline R\&D spending & 403 & 32318.14 & 77990.15 & 174 & 483676 \\
\hline Labor share in GDP & 481 & 54.79148 & 8.626994 & 29.3 & 72.4 \\
\hline
\end{tabular}

Source: own elaboration. 
Panel regression models with so-called fixed effects were chosen as the analysis method, and the parameters of those models proved consistent with the Hausman test. The following results were obtained (Table 4).

Table 4. Results of the research into the impact of FDI on GDP growth and Labor Income Share of \% GDP

\begin{tabular}{|c|c|c|c|c|c|}
\hline & Coef. & Std. Err. & z & $P>z$ & [95\% Conf. Interval] \\
\hline \multicolumn{6}{|c|}{ GDP growth } \\
\hline FDI & 0.018753 & 0.009149 & 2.05 & 0.041 & $.0007669, .0367392$ \\
\hline _ cons & 3.790561 & 0.456381 & 8.31 & 0 & $2.893329,4.687793$ \\
\hline \multicolumn{6}{|c|}{ Labour Income Share of \% GDP } \\
\hline FDI & -0.02179 & 0.004686 & -4.65 & 0 & -0.031 \\
\hline _ cons & 55.67158 & 0.229268 & 242.82 & 0 & 55.2208 \\
\hline
\end{tabular}

Source: own elaboration.

The research conducted has confirmed the existence of a statistically significant correlation between the FDI level and economic growth and the labor income share of GDP. The results obtained show that the volume of FDI has a significant positive impact on economic growth (test statistic 2.05; $p=0,041<$ significance level 0.05), i.e. when the FDI level increases by one unit, the GDP growth ratio increases on average by 0.018753 units. Meanwhile, we recorded an inverse correlation for FDI and labor income levels. When the FDI level increases by one unit, the labor income share of GDP falls on average by 0.02179 units. The obtained results indicate that this correlation is significant (test statistic -4.65; $\mathrm{p}<$ significance level 0.05). Moreover, considering both the individual and random effects, FDI has no significant impact on the level of R\&D spending (see Table 5).

Table 5. Results of research into the impact of FDI on R\&D spending in USD millions

\begin{tabular}{|l|c|c|}
\hline \multicolumn{1}{|c|}{ Variable } & RandDRE & RandDFE \\
\hline FDI & 29.929055 & 31.0132 \\
\hline${ }^{\text {cons }}$ & $30194.742^{*}$ & $33574.474 * * *$ \\
\hline N & 352 & 352 \\
\hline r2 & & 0.007002 \\
\hline r2 $\_$a & & -0.09604 \\
\hline
\end{tabular}

Source: own elaboration. 


\section{Summary}

Tax policy is undoubtedly more difficult today than it was in the past when national economies were largely separated from the rest of the world by means of trade barriers and restrictions on the flow of capital. International corporations that manipulate financial results declared in individual countries or the possibility of hiding income and assets in tax havens constitute a serious limitation for independent decisions on the type and rates of taxes. Probably the most famous design is the so-called double Irish with a Dutch sandwich. Among others, Zucman (2014) describes how this mechanism was used by Google.

However, there is no proof that the tax collector is necessarily bound to lose. The deepening international cooperation of tax services and the works on coordinating tax policy bring results, while large differences in the basic parameters of tax policy between different countries show that taxes remain an effective instrument at the disposal of nation-states.

Another important finding of our article is the limited positive impact of the FDI inflow on host countries. Even if the GDP growth seems to be accelerated by the inflow of capital, other crucial variables like R\&D spending and wage level do not benefit from FDI inflow.

The outbreak of the pandemic of Covid-19 will be of great importance for the functioning of the world economy. The public sector has a special role to play, as it is essentially responsible for economic sectors (healthcare, research, security, the coordination of international cooperation) directly related to the fight against the epidemic. No less important is support for the receding economy, which requires an active monetary and fiscal policy, as it happened in exceptional periods in world history (The Economist, 2020a). In addition to the increase in public debt, tax policy must also gain in importance, since if the role of the state in the economy grows, then its income must also increase. Despite undoubtedly objective problems with collecting taxes, the public sector is not in a lost position, and the possibilities of active tax policy are still large. In this text, we tried to show that:

- international coordination in the field of cooperation between tax services brings effects both in terms of the current collection of tax liabilities and the creation of regulations that hinder tax avoidance and understatement, 
- the benefits to be derived from investing FDI in a given country are not as obvious as it is often pointed out, hence tax competition aimed at attracting foreign capital should be reviewed,

- the role of tax havens has ceased to increase, and it can be seen that this problem is less relevant for taxpayers from OECD countries, where tax rates are relatively high,

- the largest corporations have a large number of free resources (The Economist, 2020b), so any increase in taxation will not have a large negative impact on the functioning of enterprises,

- social moods resulting from the observation of tax avoidance and evasion by individuals and corporations are becoming increasingly important; the tax collection system should have the support of public opinion, which increasingly understands the key role of the public sector in the modern economy.

Conflict of interest statement: On behalf of all authors, the corresponding author states that there is no conflict of interest.

\section{References}

Andrews, D. (1994). Capital Mobility and State Autonomy: Toward a Structural Theory of International Monetary Relations. International Studies Quarterly, 38, 193-218. https://doi.org/10.2307/2600975.

Admati, A.R. and Skeptical, A. (2017). View of Financialized Corporate Governance. Journal of Economic Perspectives, 31(3), 131-150. https://doi.org/10.1257/jep.31.3.131.

Alstadsæter, A., Johannesen, N., and Zucman, G. (2017). Who Owns the Wealth in Tax Havens? Macro Evidence and Implications for Global Inequality. NBER Working Paper No. 23805. https://doi.org/10.3386/w23805.

Auerbach, A. and Bradford, D. (2004). Generalized cash flow taxation. Journal of Public Economics, 88, 957-980. https://doi.org/10.1016/S0047-2727(03)00044-6.

Beebeejaun, A. (2018). The Efficiency of Transfer Pricing Rules as a Corrective Mechanism of Income Tax Avoidance. Journal of Civil and Legal Sciences, 7(237). https://doi.org/10.4172/2169-0170.1000237.

Bretschger, L. and Hettich, F. (2002). Globalization, capital mobility and tax competition: theory and evidence for OECD countries. European Journal of Political Economy, 18. https://doi.org/10.1016/S0176-2680(02)00115-5.

Cerny, P.G. (1995). Globalisation and the Changing Logic of Collective Action. International Organization, 49(4), 595-625. https://doi.org/10.1017/S0020818300028459.

Cheibub, J.A. (1998). Political Regimes and the Extractive Capacity of Governments: Taxation in Democracy and Dictatorships. World Politics, 50(3), 349-376. https://doi.org/10.1017/S0043887100012843.

Garrett, G. and Mitchell, D. (2001). Globalization, government spending and taxation in the OECD. European Journal of Political Research, 39(2), 145-177. https://doi.org/10.1111/1475-6765.00573.

Gilpin, R. (2000). The Challenge of Global Capitalism: The World Economy in the 21st Century. Princeton: Princeton University Press. https://doi.org/10.1515/9780691186474.

International Monetary Fund (2019). IMF Fiscal Monitor, April 2019. 
Kahle, K.M. and Stulz, R.M. (2017). Is the US Public Corporation in Trouble? Journal of Economic Perspectives, 31(3), 67-88. https://doi.org/10.1257/jep.31.3.67.

Kleven H.J. (2014). How Can Scandinavians Tax So Much? Journal of Economic Perspectives, 28(4), 77-98. https://doi.org/10.1257/jep.28.4.77.

King, S.D. (2010). Losing Control. The Emerging Threats to Western Prosperity. New Haven-London: Yale University Press.

Kolodko, G.W. (2016). How to Destroy a Country. The Economics and the Politics of the Greek Crisis. Rivista di Politica Economica, 2(IV-VI), 37-61. https://doi.org/10.2139/ssrn.3036957.

Krugman, P. (2009). How Did Economist Get It So Wrong? The New York Times. 2 September 2009.

Kudrle, R.T. (2008). The OECD's Harmful Tax Competition Initiative and the Tax Havens: from Bombshell to Damp squib. Global Economy Journal, 8(1). https://doi.org/10.2202/1524-5861.1329.

Legrain, Ph. (2010). Aftershock: Reshaping the World Economy After the Crisis. London: Little Brown.

Massey, C. and Thaler, R.H. (2012). The Loser's Curse: Decision Making \& Market Efficiency in the National Football League Draft. https://ssrn.com/abstract=697121 or https://doi.org/10.2139/ssrn.697121.

Oxfam (2019). Off the hook: how the EU is about to whitewash the world's worst tax havens. https://www.oxfam.org/en/research/hook-how-eu-about-whitewash-worlds-worst-tax-havens.

Rajan R. (2010). Fault Lines: How Hidden Fractures Still Threaten the World Economy. Princeton: Princeton University. https://doi.org/10.1515/9781400839803.

Remeur, C. (2017). Understanding the Rationale for Compiling 'Tax Haven' Lists. European Parliament Research Service Briefing. http://www.europarl.europa.eu/RegData/etudes/BRIE/2017/614633/EPRS_BRI(2017)614633_EN.pdf.

Shaxson, N. (2016). Will the OECD Tax Haven Blacklist be Another White Wash? https://www.taxjustice.net/2016/07/20/oecd-another-go-hopeless-politicised-tax-haven-blacklisting.

Shaxson, N. and Christensen, J. (2016). Tax Competitiveness - a Dangerous Obsession. In: Th. Pogge and K. Mehta (eds.), Global Tax Fairness. Oxford: Oxford University Press. https://doi.org/10.1093/acprof:oso/9780198725343.003.0013.

Sheppard, L.A. (2017). The United States as Tax Haven. https://moodysgartner.com/wp-content/uploads/US-as-a-tax-haven-20170626.pdf.

Stiglitz, J.E. (2018). The Euro: How a Common Currency Threatens the Future of Europe. New York: W.W. Norton \& Company.

Tanzi, V. (2000). Globalization, Technological Developments, and the Work of Fiscal Termites. IMF Working Paper No. 00/181. https://doi.org/10.5089/9781451859188.001.

The Economist (2020a). Building up the pillars of state. The Economist, March 28th.

The Economist (2020b). Best in show. The Economist, March 28th.

Torslov, L., Wier, L. and Zucman, G. (2018). The Missing Profits of Nations. NBER working paper No. 24701. https://doi.org/10.3386/w24701.

Wright, T. and Zucman, G. (2018). The Exorbitant Tax Privilege. NBER working paper No. 24983. https://doi.org/10.3386/w24983.

Zingales, L. (2017). Towards a Political Theory of the Firm. Journal of Economic Perspectives, 31(3), 113-130. https://doi.org/10.1257/jep.31.3.113.

Zucman, G. (2014). Taxing Across Boarder: Tracking Personal Wealth and Corporate Profits. Journal of Economic Perspectives, 28(4), 121-148. https://doi.org/10.1257/jep.28.4.121. 